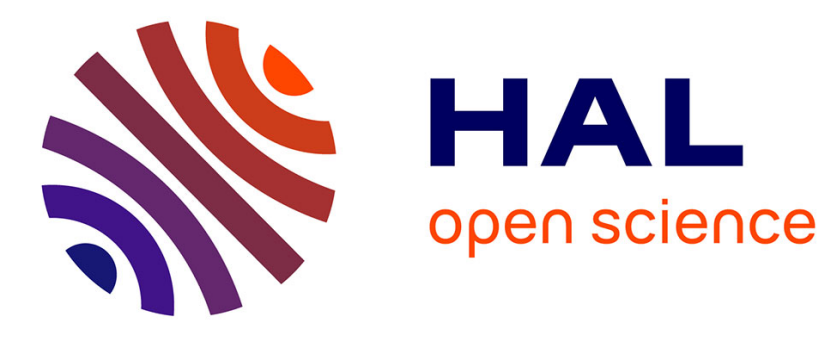

\title{
Integrative approach of tomato fruit texture using multi-block analysis
}

Rémy Aurand, Mireille Faurobert, Mohamed Hanafi, Gérard Mazerolles, Raphaël Tisiot, Laurent Rosso, Brigitte Navez, Nadia Bertin

\section{- To cite this version:}

Rémy Aurand, Mireille Faurobert, Mohamed Hanafi, Gérard Mazerolles, Raphaël Tisiot, et al.. Integrative approach of tomato fruit texture using multi-block analysis. 2. Symposium on Horticulture in Europe, Jul 2012, Angers, France. hal-01595152

\section{HAL Id: hal-01595152 \\ https://hal.science/hal-01595152}

Submitted on 3 Jun 2020

HAL is a multi-disciplinary open access archive for the deposit and dissemination of scientific research documents, whether they are published or not. The documents may come from teaching and research institutions in France or abroad, or from public or private research centers.
L'archive ouverte pluridisciplinaire HAL, est destinée au dépôt et à la diffusion de documents scientifiques de niveau recherche, publiés ou non, émanant des établissements d'enseignement et de recherche français ou étrangers, des laboratoires publics ou privés. 
